Proceedings of Symposium

\title{
Effects of an Endocrine Disruptor on Male Reproductive Organs
}

\author{
Yasuyoshi Okuno $^{1}$ and Kaori Miyata ${ }^{1}$ \\ ${ }^{1}$ Environmental Health Science Laboratory, Sumitomo Chemical Co., Ltd, Osaka 554-8558, Japan
}

\begin{abstract}
A 5-day Hershberger assay, a 20-day pubertal male assay, a one-month oral administration study and a reproductive toxicity study were carried out using an antiandrogenic chemical, flutamide (FL). The effects of FL were as follows: weight decrease in male reproductive organs such as the prostate and seminal vesicles were observed at $\geq 0.6$ $\mathrm{mg} / \mathrm{kg} / \mathrm{day}$ as the most sensitive parameter in the Hershberger assay and the one-month oral administration study. Reduction in number of spermatogenic cells was found at $\geq 0.6 \mathrm{mg} / \mathrm{kg} /$ day as the most sensitive parameter in the 20-day pubertal male assay. A decrease in the anogenital distance was observed at $\geq 2.5 \mathrm{mg} / \mathrm{kg} /$ day as the most sensitive parameter in the reproductive toxicity study. These effects were compared with the reported results of one-month oral administration study of an estrogenic chemical, ethinylestradiol (EE), and an androgenic chemical, methyltestosterone (MT). Differences in the results were as follows: serum hormone levels of LH and testosterone were increased by the FL-treatment, but decreased with EE despite testicular atrophy in all cases. While EE and MT produced atrophic changes in Leydig cells, FL induced their hyperplasia. Thus, different results were obtained regarding serum hormone levels and histopathological changes in Leydig cells with the endocrine disruptor. Attention should be concentrated on these two parameters to clarify and characterize the mechanisms of action of so called endocrine disruptors.

(J Toxicol Pathol 2001; 14: 79-82)
\end{abstract}

Key words: male reproductive organs, endocrine disruptors, flutamide, ethinylestradiol, methyltestosterone

\section{Introduction}

There are several known mechanisms of male reproductive toxicity with direct effects of chemicals or indirect influence via hormonal disturbance, alteration of local blood circulation and malnutrition. The present study is concerned with indirect effects via hormonal disturbance produced by an endocrine disrupting chemical. The presented data relate to toxicity to male reproductive organs of FL, compared with those of EE and MT. The paper was prepared for the Proceedings of a symposium entitled "Toxicological Changes in Endocrine Organs and Endocrine Disruptors" at the 16th annual meeting of Japanese Society of Toxicologic Pathology: Gifu, 2000.

\section{Effects of an Antiandrogenic Chemical, FL on Male Reproductive Organs}

A 5-day Hershberger assay, a 20-day pubertal male assay, a one-month oral administration study and a reproductive toxicity study were carried out using the antiandrogenic chemical, FL. Various toxic effects on male

Mailing address: Yasuyoshi Okuno, Environmental Health Science Laboratory, Sumitomo Chemical Co., Ltd., 3-1-98, Kasugade-Naka, Konohana-Ku, Osaka 554-8558, Japan reproductive organs were found in these studies. The procedures and results can be summarized as follows:

Five-day hershberger assay utilizing mature male rats

Male $\mathrm{Crj}: \mathrm{CD}(\mathrm{SD}) \mathrm{IGS}$ rats (10 weeks of age, 6 rats/ group) were castrated and immediately implanted with plastic tubes containing testosterone ${ }^{1}$. Seven days thereafter, they were dosed for 5 days by gavage with FL $(0,0.15,0.6$, 2.5 and $10 \mathrm{mg} / \mathrm{kg} /$ day). One day after the last dosing, the rats were sacrificed for examination. FL produced significant decrease in weights of the seminal vesicles and the levator ani plus bulbocavernosus (LABC) muscles $(\geq 0.6 \mathrm{mg} / \mathrm{kg} /$ day) and ventral prostate ( $\geq 2.5 \mathrm{mg} / \mathrm{kg} /$ day), and an increase in the serum luteinizing hormone (LH) level $(\geq 2.5 \mathrm{mg} / \mathrm{kg} /$ day). On histopathological examination, atrophic changes were found in the prostate and the seminal vesicle $(\geq 2.5 \mathrm{mg} /$ $\mathrm{kg} /$ day), as well as in the $\mathrm{LABC}$ muscle $(10 \mathrm{mg} / \mathrm{kg} /$ day $)$.

\section{Twenty-day pubertal male assay}

Immature male Crj: $\mathrm{CD}(\mathrm{SD}) \mathrm{IGS}$ rats (22-23 days of age, 10 rats/group) were treated by gavage with FL $(0,0.15,0.6$, 2.5 and $10 \mathrm{mg} / \mathrm{kg} / \mathrm{day}$ ) for 20 days ${ }^{1}$. One day after the last dosing, they were sacrificed for examination. FL produced significant decrease in weights of the seminal vesicles, the ventral prostate, the epididymides and the LABC muscles at $\geq 2.5 \mathrm{mg} / \mathrm{kg} / \mathrm{day}$. Serum LH levels were significantly 
increased at $10 \mathrm{mg} / \mathrm{kg} / \mathrm{day}$. On histopathological examination, atrophic changes were found in the seminal vesicles $(\geq 2.5 \mathrm{mg} / \mathrm{kg} /$ day $)$, as well as in the ventral prostate and the LABC muscle $(10 \mathrm{mg} / \mathrm{kg} /$ day $)$. Leydig cell hyperplasia was also found at $10 \mathrm{mg} / \mathrm{kg} / \mathrm{day}$. Numbers of spermatogenic cells per Sertoli cell were decreased at $\geq 0.6$ $\mathrm{mg} / \mathrm{kg} / \mathrm{day}$.

\section{One-month oral administration study}

Male Crj:CD(SD)IGS rats (7 weeks of age, 10 rats/ group) were treated by gavage with flutamide $(0,0.15,0.6$, 2.5 and $4 \mathrm{mg} / \mathrm{kg} / \mathrm{day}$ ) for 28-30 days. One day after the last dosing, they were sacrificed and examined. FL produced significant decrease in weights of the seminal vesicles and the dorso-lateral prostate at $\geq 0.6 \mathrm{mg} / \mathrm{kg} /$ day and ventral prostate at $\geq 2.5 \mathrm{mg} / \mathrm{kg} /$ day. Serum testosterone (T) levels were significantly increased at $4 \mathrm{mg} / \mathrm{kg} /$ day. Serum follicular stimulating hormone $(\mathrm{FSH})$ levels were significantly increased at $\geq 2.5 \mathrm{mg} / \mathrm{kg} / \mathrm{day}$. On histopathological examination, atrophy was evident in the mammary gland ( $\geq 2.5 \mathrm{mg} / \mathrm{kg} / \mathrm{day})$, but no remarkable changes were observed in male reproductive organs of treated rats. (This study was supported by a grant from New Energy and Industrial Technology Development Organization).

\section{Reproductive toxicity (in utero and perinatal exposure) study}

Pregnant female Crj:CD(SD)IGS rats were treated by gavage with FL $(0,0.15,0.6,2.5,10$ and $100 \mathrm{mg} / \mathrm{kg} /$ day $)$ from day 14 of pregnancy to day 3 of lactation. Male offsprings (31-47 and 10-12 rats/group) were sacrificed at 4 and 60 days, respectively. On clinical observation, several abnormalities such as nipple retention, undescended testes and hypospadias were observed at $\geq 10 \mathrm{mg} / \mathrm{kg} /$ day. At 4 days of age, small testes and defects of accessory sex organs were noted at necropsy of $\geq 10$ and $100 \mathrm{mg} / \mathrm{kg} / \mathrm{day}$, respectively. Anogenital distance was significantly decreased at $\geq 2.5 \mathrm{mg} /$ $\mathrm{kg}$ /day at 21 days of age. Number of sperm, measured at 60 days of age, was significantly decreased at $\geq 10 \mathrm{mg} / \mathrm{kg} /$ day. At 60 days of age, significant decrease in weights of the testis, the LABC muscle and the seminal vesicles at $100 \mathrm{mg} /$ $\mathrm{kg}$ /day as well as in weight of the LABC muscle and the prostate at $10 \mathrm{mg} / \mathrm{kg} / \mathrm{day}$ was observed. On histopathological examination, atrophic changes in the LABC muscle, prostate, seminal vesicles and seminiferous tubules and vacuolation of Sertoli cells were found at $\geq 10$ $\mathrm{mg} / \mathrm{kg} /$ day. In addition, stratified squamous metaplasia in the epithelium of the urethral diverticulum was observed at $\geq 10 \mathrm{mg} / \mathrm{kg} / \mathrm{day}$ and goblet cells were also found in the epithelium at $100 \mathrm{mg} / \mathrm{kg} /$ day.

\section{Comparison of No-effect Levels among Studies with FL}

The no-effect levels in the studies with FL are compared in Table 1. Weight decrease in male reproductive organs was the most sensitive parameter in the Hershberger assay and the one-month oral administration study. Decrease in number of spermatogenic cells was the most sensitive parameter in the 20-day pubertal male assay. Anogenital distance was the most sensitive parameter in the reproductive toxicity study. The reproductive study was less sensitive when compared with the other 3 studies for the detection of anti-androgenic activity of FL. Thus, the Hershberger assay, 20-day pubertal male assay and onemonth oral administration study (OECD 407 study) are best candidates for in vivo screening for this type of endocrine disruptor. The present results imply that they have excellent sensitivity for detection of antiandrogenic activity.

Table 1. Comparison of No-effect Levels among Studies of Flutamide

\begin{tabular}{|c|c|c|c|c|c|c|}
\hline \multirow[t]{2}{*}{ Study } & \multirow[t]{2}{*}{ Most sensitive parameters } & \multicolumn{5}{|c|}{ Dosage } \\
\hline & & 0.15 & 0.6 & 2.5 & 10 & 100 \\
\hline $\begin{array}{l}\text { Hershberger } \\
\text { Assay }\end{array}$ & $\begin{array}{l}\text { Weight decrease of seminal } \\
\text { vesicles and Levator ani plus } \\
\text { bulbocavernosus muscle }\end{array}$ & & & & & \\
\hline $\begin{array}{l}\text { 20-day Pubertal } \\
\text { Male Assay }\end{array}$ & $\begin{array}{l}\text { Decrease in number of } \\
\text { spermatogenic cells } \\
\text { per Sertoli cell }\end{array}$ & & & & & \\
\hline $\begin{array}{l}\text { One-Month Oral } \\
\text { Administration Study }\end{array}$ & $\begin{array}{l}\text { Weight decrease of } \\
\text { dorso-lateral prostate } \\
\text { and seminal vesicles }\end{array}$ & & & & $\mathrm{NE}$ & $\mathrm{NE}$ \\
\hline $\begin{array}{l}\text { Reproductive } \\
\text { Toxicity Study }\end{array}$ & $\begin{array}{l}\text { Shortening of the anogenital } \\
\text { distance }\end{array}$ & & & & & \\
\hline
\end{tabular}




\section{Effects of an Estrogen, EE, on Male Reproductive Organs}

Iwase $e t a l .^{2}$ carried out a one-month oral administration study with the estrogen, EE. Male $\mathrm{Crj}: \mathrm{CD}(\mathrm{SD})$ rats (10 weeks of age, 10 rats/group) were treated by gavage with $\mathrm{EE}(0,0.1,0.3,3$ and $10 \mathrm{mg} / \mathrm{kg} /$ day $)$ for 34-41 days. One day after the last dosing, they were sacrificed and examined. EE produced significant decrease in weights of the testes, seminal vesicles and the ventral prostate at all doses and epididymides at $\geq 0.3 \mathrm{mg} / \mathrm{kg} / \mathrm{day}$. Numbers of sperm were decreased at all doses. On histopathological examination, atrophic changes of the seminiferous tubules and Leydig cells and vacuolation of Sertoli cells were found at all doses along with atrophy of epididymides, ventral prostate and seminal vesicles.

\section{Effects of an Androgen, MT, on Male Reproductive Organs}

A one-month oral administration study with an androgen, MT, was carried out at the National Institute of Hygienic Sciences ${ }^{3}$. Male Crj:CD(SD) IGS rats (7 weeks of age, 10 rats/group) were treated by gavage with $\mathrm{MT}(0,5,20$ and $80 \mathrm{mg} / \mathrm{kg} /$ day) for 28 days. One day after the last dosing, they were sacrificed and examined. No treatmentrelated changes were observed in serum hormone levels such as testosterone and LH. However, MT produced significant decrease in weights of the testes and the epididymides at 80 $\mathrm{mg} / \mathrm{kg} / \mathrm{day}$. On histopathological examination, atrophy of the seminiferous tubules and Leydig cells, degenerative changes in the pachytene spermatocytes and retention of degenerated germ cells in the epididymis were found at 80 $\mathrm{mg} / \mathrm{kg} /$ day.

\section{Discussion}

In order to characterize effects on male reproductive organ caused by an endocrine disruptor, FL, a comparison with EE and MT was here performed to allow possible mechanisms to be assessed.
Characteristics of the effect on serum hormone levels and the histopathological findings caused by endocrine disruptors

The effects on serum hormone levels and histopathological findings in the above studies are summarized in Table 2. The serum hormone levels of LH and testosterone were increased in the FL-treated groups. On the contrary, they were decreased by EE and not affected by MT. While all the chemicals caused testicular atrophy, only EE and MT produced the atrophic changes of Leydig cells, FL in contrast causing their hyperplasia. Thus, the different results were revealed for serum hormone levels and histopathological findings of Leydig cells. Cook et al. ${ }^{4}$ reported antiandrogenic chemicals to cause proliferative changes of Leydig cells and in another study found $17 \beta$ estradiol produce lowering of serum hormone levels and the atrophy of Leydig cells. Therefore, the differences observed here might be general characteristics allowing distinction of endocrine disruptors.

\section{Possible mechanisms of the effects of FL on the male reproductive systems}

There are several reports and reviews regarding the mechanisms of endocrine disruption $\left(\mathrm{Creasy}^{8}\right.$, Kelce et al. ${ }^{9}$, Abney $\left.{ }^{10}\right)$. It has been reported that FL blocks the physiological action of testosterone at androgenic receptor sites and thus causes effects on various organs, tissues or cells ${ }^{8}$. This conclusion was supported by a recent study where FL altered steady-state levels of specific androgen receptor-regulated gene expression in vivo ${ }^{9}$. Therefore, it can be speculated that FL causes the atrophic changes of seminiferous tubules through depressing the function of Sertoli cells and that the higher levels of serum LH are due to a block of the negative feedback loop between the pituitary and the testis. The hyperplasia of Leydig cells is presumably related to the elevation of LH. The lowering of accessory sex organ weights may be attributable to interference with the physiological action of testosterone.

Several studies suggest that estrogenic chemicals directly cause functional damage to Leydig cells and inhibit their proliferation ${ }^{10}$. Atrophic changes of Leydig cells were

Table 2. Characteristic effects on serum hormone levels and histopathological findings caused by an endocrine disruptor, FL and two hormones, EE and MT

\begin{tabular}{|c|c|c|c|}
\hline Parameters & $\begin{array}{l}\text { Antiandrogenic } \\
\text { chemical (FL) }\end{array}$ & $\begin{array}{c}\text { Estrogenic } \\
\text { Chemical (EE) }\end{array}$ & $\begin{array}{c}\text { Androgenic } \\
\text { Chemical (MT) }\end{array}$ \\
\hline $\begin{array}{l}\text { Serum Hormone Levels } \\
\text { Testosterone, LH } \\
\text { Histopathological examination }\end{array}$ & Increase & Decrease ${ }^{a, b)}$ & No change \\
\hline $\begin{array}{l}\text { Testis; Seminiferous tubules } \\
\text { Leydig cells } \\
\text { Sertoli cells } \\
\text { Prostate, Seminal vesicle }\end{array}$ & $\begin{array}{l}\text { Atrophy } \\
\text { Hyperplasia } \\
\text { Vacuolation } \\
\text { Atrophy }\end{array}$ & $\begin{array}{l}\text { Atrophy } \\
\text { Atrophy } \\
\text { Vacuolation } \\
\text { Atrophy }\end{array}$ & $\begin{array}{l}\text { Atrophy } \\
\text { Atrophy }\end{array}$ \\
\hline
\end{tabular}

a) $3 \mathrm{mg} / \mathrm{kg} /$ day, 1-3 weeks; Tsuchiya et al. ${ }^{6}$.

b) 1 and $10 \mathrm{mg} / \mathrm{kg} /$ day, 3 days-4 weeks; Kaneto et al. ${ }^{7}$. 
here observed in the EE-treated, the functional damage being related to lower levels of serum testosterone which would be expected to cause atrophy of seminiferous tubules and depressed organ weights.

It has been speculated that androgenic chemicals cause effects on sex organs via blocking negative feedback loop between the pituitary and the testis ${ }^{10}$. While no alteration in serum hormone levels was observed in the MT-treated rats, it might be necessary to investigate whether effects were expected at an early stage in this one-month study.

In order to generalize characteristics and find the best parameters to distinguish endocrine disruptors, more information is essential. However, from the present study, measurement of serum hormone levels and histopathological examination can be concluded to give important information in terms of mechanistic considerations.

Acknowledgments: The author acknowledges the help of Drs. M. Hirose, T. Imazawa and K. Yasuhara (National Institute of Hygienic Sciences) in providing important information on methyltestosterone and Drs. M. Mutai and F. Sano (Mitsubishi-Tokyo Pharmaceuticals, Inc.) who provided essential data for ethinylestradiol. The author also thanks Drs. A. Hagiwara and M. Sano, Ms. H. Yoshino, and Mr. T. Nakanishi (Daiyu-Kai Institute of Medical Science) for their collaboration work on the reproductive toxicity study with flutamide. The author would further like to express his appreciation to other contributors to this research project in the Environmental Health Science Laboratory of Sumitomo Chemical Co. Ltd.: Mr. T. Sukata, Ms. S. Yabushita, Mr. M. Ozaki, Dr. S. Uwagawa, Ms. K. Yoshioka, Dr. T. Yamada, Mr. T. Kunimatsu, Mr. O. Sunami and Ms. K. Ose.

\section{References}

1. Yamada T, Kunimatsu T, Sako H, Yabushita S, Sukata T,
Okuno Y, and Matsuo M. Comparative evaluation of a 5-day Hershberger assay utilizing mature male rats and a pubertal male assay for detection of flutamide's antiandrogenic activity. Toxicol Sci 2000; 53: 289-296.

2. Iwase T, Sano F, Murakami T, and Inazawa K. Male reproductive toxicity of ethinylestradiol associated with 4 weeks daily dosing prior to mating in rats. J Toxicol Sci 1995; 20: 265-279.

3. Hirose M. National Institute of Hygienic Sciences. Personal communication, 1999.

4. Cook JC, Klinefelter GR, Hardisty JF, Sharpe RM, and Foster PMD. Rodent Leydig cell tumorigenesis: A review of the physiology, pathology, mechanisms, and relevance to humans. Critical Rev in Toxicol 1999; 29: 169-261.

5. Cook JC, Johnson L, O'Connor JC, Biegel LB, Krams CH, Frame SR, and Hurtt ME. Effect of dietary $17 \beta$-estradiol exposure on serum hormone concentrations and testicular parameters in male Crl:CD BR rats. Toxicol Sci 1998; 44: 155-168.

6. Tsuchiya T, Sano F, Sugimoto J, Kobayashi K, Goto K, and Mutai M. Abstracts of Papers, the 15th Annual Meeting of Japanese Society of Toxicologic Pathology: Mito, Ibaraki, 1999; Abstract P-55.

7. Kaneto M, Kanamori S, Hishikawa A, and Kishi K. Epididymal sperm motion as a parameter of male reproductive toxicity: sperm motion, fertility, and histopathology in ethinylestradiol-treated rats. Reproductive Toxicol 1999; 13: 279-289.

8. Creasy DM. Hormonal mechanisms in male reproductive tract toxicity. In : Endocrine and Hormonal Toxicology, PW Harvey, KC Rush and A Cockburn. (eds), New York : John Wiley \& Sons, 355-405, 1999.

9. Kelce WR, Lambright CR, Gray LE, and Roberts KP. Vinclozolin and p.p'-DDE alter androgen-dependent gene expression: In vivo confirmation of an androgen receptormediated mechanism. Toxicol App Pharmacol 1997; 142: 192-200.

10. Abney TO. The potential roles of estrogen in regulating Leydig cell development and function: A review. Steroids 1999; 64: 610-617. 